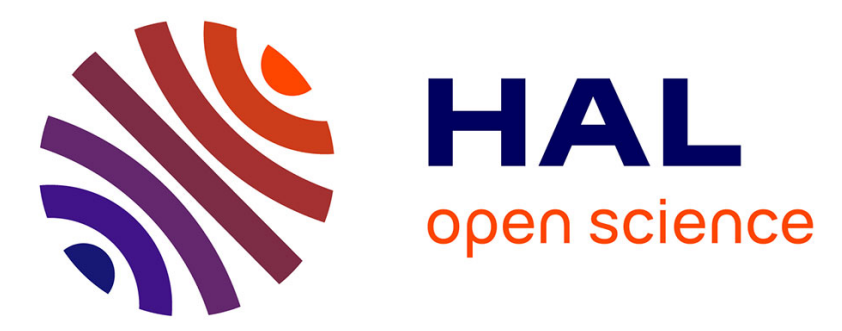

\title{
Regioselective addition of DDQ on a quinoid ring: an entry into chiral zwitterionic bridging ligands
}

Gabriel Canard, Zhongrui Chen, Aprilliyani Suryaningtias, Marion Jean, Nicolas Vanthuyne, Michel Giorgi, Christian Roussel, Olivier Siri

\section{To cite this version:}

Gabriel Canard, Zhongrui Chen, Aprilliyani Suryaningtias, Marion Jean, Nicolas Vanthuyne, et al.. Regioselective addition of DDQ on a quinoid ring: an entry into chiral zwitterionic bridging ligands. New Journal of Chemistry, 2018, 42 (10), pp.8247-8252. 10.1039/c7nj03765a . hal-02460761

\section{HAL Id: hal-02460761 https://hal.science/hal-02460761}

Submitted on 30 Jan 2020

HAL is a multi-disciplinary open access archive for the deposit and dissemination of scientific research documents, whether they are published or not. The documents may come from teaching and research institutions in France or abroad, or from public or private research centers.
L'archive ouverte pluridisciplinaire $\mathbf{H A L}$, est destinée au dépôt et à la diffusion de documents scientifiques de niveau recherche, publiés ou non, émanant des établissements d'enseignement et de recherche français ou étrangers, des laboratoires publics ou privés. 


\section{Regioselective addition of DDQ on a quinoid ring: an entry into chiral zwitterionic bridging ligands}

Gabriel Canard, ${ }^{* \mathrm{a}}$ Zhongrui Chen, ${ }^{\mathrm{a}}$ Aprilliyani Suryaningtias, ${ }^{\mathrm{a}}$ Marion Jean, ${ }^{\mathrm{b}}$ Nicolas Vanthuyne, ${ }^{\mathrm{b}}$ Michel Giorgi, ${ }^{\mathrm{c}}$ Christian Roussel ${ }^{b}$ and Olivier Siri*a

The regioselective insertion of DDQ into a $\mathrm{C}-\mathrm{H}$ bond of the $6 \pi+6 \pi$ electron zwitterionic benzoquinonemonoimines $4 a-c$ results in the formation of the novel chiral C-substituted quinoid ligands 11a-c. These Michael adducts feature a preserved zwitterionic form and a quaternary stereogenic carbon center as evidenced by the single crystal X-ray structure of the derivative 11a. The ECD spectra, optical rotations and racemization barriers of the two enantiomers of 11a were measured subsequently to their separation by a preparative chiral HPLC. Because the racemization of 11a is stopped in basic media, compounds 11a-c give a new entry in chiral zwitterionic bridging ligands.

\section{Introduction}

The 2,5-dihydroxy-1,4-benzoquinone 1 (Figure 1) featuring a [0,0,0,0] donor set has been extensively used as a bridging ligand to build polymetallic complexes where the effective intermetallic communication can lead, for example, to spin-spin couplings or mixed-valence states. ${ }^{1}$ During the last decades, several new classes of bridging ligands were developed by replacing from one to four of the "O" groups of $\mathbf{1}$ by isoelectronic "NR" ones producing the "amino/imino" quinoid ligands 2-6 (Figure 1). ${ }^{2}$ These replacements can tune the physico-chemical properties of the resulting metallic complexes by introducing unsymmetrical donor sets and/or by selecting the steric and electronic characteristics of the R substituents. ${ }^{2}$ Interestingly, when two amino fragments are introduced on the quinoid skeleton in $\mathbf{3}$ and $\mathbf{4}$, two different electronic distributions are obtained. Indeed, if the quinoidal structure is retained in the structure of $\mathbf{3}$ having a $[\mathrm{N}, \mathrm{O}, \mathrm{N}, \mathrm{O}]$ donor set, the $[\mathrm{N}, \mathrm{N}, \mathrm{O}, \mathrm{O}]$ coordinating system of $\mathbf{4}$ induces an intramolecular proton transfer producing a zwitterion being more stable than its corresponding canonical form (Figure 1 ). ${ }^{3}$

This zwitterionic form gives rise to specific physico-chemical properties such as a permanent electric dipole that can guide the self-assembly of $\mathbf{4}$ derivatives on surfaces. ${ }^{4}$ The zwitterion 4 is also, as the other members of 1-6 series, an efficient coordinating ligand and was incorporated into metallic complexes ${ }^{5}$ that were applied in catalysis, ${ }^{6}$ optical recording, ${ }^{7}$ electrochromism ${ }^{8}$ or vapochromism. ${ }^{9}$ On the other hand, this particular electronic distribution of $\mathbf{4}$ gives rise to two different kinds of reactivity towards organic and electrophilic reagents (Figure 2).<smiles>O=C1C=C(O)C(=O)C=C1O</smiles><smiles>NC1=CC(=O)C(O)=CC1=O</smiles>

1

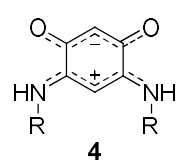

2

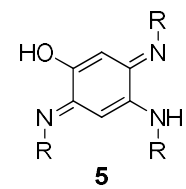<smiles>[R]NC1=CC(=O)C(N[R])=CC1=O</smiles><smiles>[R]N=C1C=C(N[R])C(=N[R])C=C1N[R]</smiles>

Fig 1. Stepwise replacement of the "O" groups of $\mathbf{1}$ by isoelectronic "NR" ones in bridging quinoid ligands 2-6.

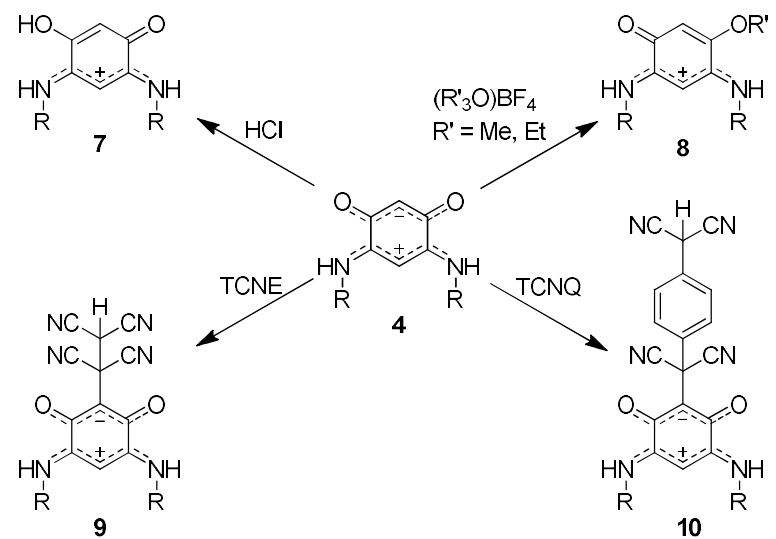

Fig 2. Previously reported reactions of 4 with electrophilic organic reagents. 
The addition of a strong acid $(\mathrm{HCl})$ or of a strong alkylating agent $\left(\left(\mathrm{R}_{3}^{\prime} \mathrm{O}\right) \mathrm{BF}_{4}\right)$ on 4 produces the localization of the upper $6 \pi$ electron system through the formation of a single $O-R^{\prime}$ bond $\left(R^{\prime}=H\right.$, Me or Et) in the positively charged derivatives 7 and 8 (Figure 2). ${ }^{10}$ On the other hand, the reaction between 4 and the organic electron acceptors tetracyanoethylene (TCNE) or $7,7^{\prime}, 8,8^{\prime}$-tetracyanoquinodimethane (TCNQ) yielded the formation of the unexpected adducts $\mathbf{9}$ and $\mathbf{1 0}$ where a regioselective carbon-carbon bond was formed between the two starting components and was preserving the zwitterionic form thanks to an intramolecular proton transfer (Figure 2). ${ }^{11}$ This insertion of TCNE or TCNQ into the central upper C-H bond was shown to bring from slight to important changes in the coordination and self-assembling properties of $\mathbf{9}$ and $\mathbf{1 0}$ derivatives compared to those of 4. ${ }^{12}$

The present work illustrates how the addition of 2,3-dichloro-5,6-dicyano-1,4-benzoquinone (DDQ) in the upper C-H bond adjacent to the $\mathrm{C}=\mathrm{O}$ bonds of $\mathbf{4}$ give rise to novel chiral zwitterionic ligands. If the single reported chiral derivatization of $\mathbf{4}$ was produced by the introduction of chiral amines on its lower N-C-C-C-N part, ${ }^{12 e}$ the present one concerns the upper $\mathrm{O}-\mathrm{C}-\mathrm{C}-\mathrm{C}-\mathrm{O}$ moiety and follows a Michael-type addition. This condensation is accompanied by i) the preservation of the zwitterionic form thanks to an intramolecular proton transfer and ii) the creation of a chiral quaternary carbon center which allowed the separation and characterization of each enantiomer of one 4-DDQ adduct.

\section{Results and discussion}

\section{Organic synthesis.}

The reaction between DDQ and the $6 \pi+6 \pi$ zwitterions $4 a-c$ at room temperature in a $1: 1$ ratio results in the progressive formation of orange-red precipitate of the adducts 11a-c (Figure 3). A first proof of the insertion of DDQ in the C-H bond of 4a-c was given by the corresponding ${ }^{1} \mathrm{H} N M R$ and ${ }^{13} \mathrm{C}$ NMR spectra recorded in DMSO- $\mathrm{d}_{6}$. For example, the two $\mathrm{C}\left(\mathrm{sp}^{2}\right)-\mathrm{H}$ signals of $4 \mathrm{a}$ located at $\delta=4.95$ and $\delta=5.47 \mathrm{ppm}$ were replaced by a single downfield shifted singlet at $\delta=5.59$ ppm in the spectrum of 11a (see the supporting information). If the disappearance of the downfield shifted ${ }^{1} \mathrm{H} N M R$ signal of $\mathrm{H}_{a}$ could result from the expected $\mathrm{C}-\mathrm{C}$ oxidative coupling between two molecules of $4 \mathrm{a}^{13}{ }^{13}$ this hypothesis was excluded by the presence of 16 signals in the ${ }^{13} \mathrm{C}$ NMR spectrum of 11 a whose structure was confirmed by high resolution mass-spectrometry and single crystal $\mathrm{X}$-ray diffraction analyses (see below).

\section{Single crystal X-ray diffraction.}

The slow cooling of a concentrated toluene solution of 11a afforded diffracting single crystals suitable for an X-ray structure analysis (Figure 4). Details of the structure determination are given in the experimental part and in Table S1 (see the supporting information). As observed previously with TCNE and TNCQ, the molecular structure of 11a revealed that a single C-C bond with a length of 1.535(9) Å has been regioselectively formed between DDQ and the zwitterion 4a.

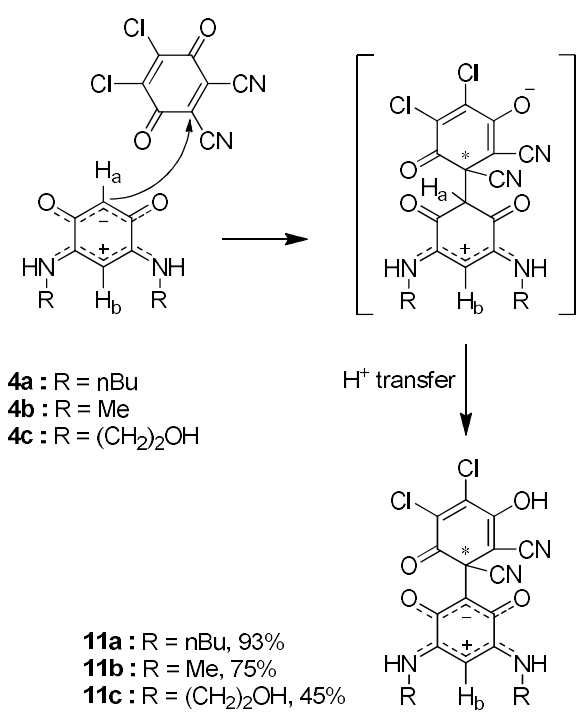

Fig 3. Reactions of $4 a-c$ with $D D Q$. 
This insertion is occurring in the $\mathrm{C}-\mathrm{H}$ bond adjacent to the two $\mathrm{C}=\mathrm{O}$ bonds of $4 \mathrm{a}$ which retains its $\mathrm{zwitterionic}$ form characterized by an equalization of the $\mathrm{C}-\mathrm{C}$ and $\mathrm{C}-\mathrm{O}$ bond lengths of its upper $\mathrm{O}-\mathrm{C}-\mathrm{C}-\mathrm{C}-\mathrm{O}$ moiety as well as the equal $\mathrm{C}-\mathrm{C}$ and $\mathrm{C}-\mathrm{N}$ bond lengths of its lower N-C-C-C-N moiety. The newly formed C-C bond involves one of the two DDQ carbon atoms bearing a cyano group as already observed when such addition occurred between DDQ and various nucleophilic carbon atoms of, for example, silyl enol ethers, ${ }^{14}$ enaminones ${ }^{15}$ or indoles. ${ }^{16}$ If the $\mathrm{C}=\mathrm{O}$ bond of the DDQ moiety adjacent to the quaternary carbon atom remains a double bond with a length of 1.203(8) $\AA$, the formation of the zwitterion 11a is resulting from a proton transfer from the two starting components confirmed by the new $\mathrm{C}-\mathrm{OH}$ single bond length of 1.334(8) $\AA$. The crystal packing of the racemic 11a revealed that each enantiomer of 11a is interacting with the other one thanks to a $\pi-\pi$ interaction producing a "tête-bêche" arrangement (Figure 4b).

a)

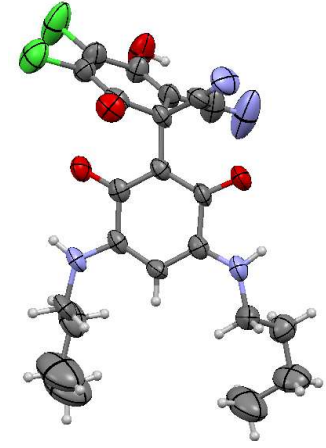

b)

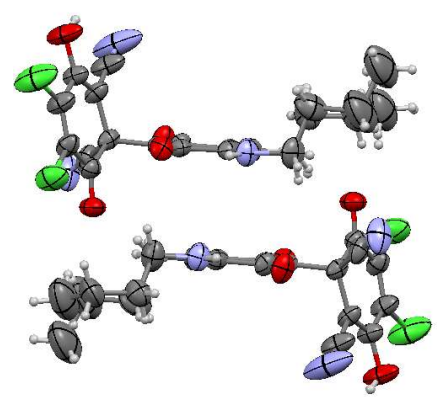

Fig 4. ORTEP views of the crystal structure of 11a showing: a) one enantiomer of 11a; b) the $\pi-\pi$ stacking interaction occurring between the two enantiomers of $11 a$ Table 1 Chiral HPLC data ((S,S)-Whelk-O1) and specific optical rotations of the two enantiomers of 11a.

\begin{tabular}{|c|c|c|c|c|c|c|c|c|c|}
\hline & & $\mathrm{t}(-)(\min )^{a}$ & $\mathrm{k}(-)^{a}$ & $\mathrm{t}(+)(\min )^{a}$ & $\mathrm{k}(-)^{a}$ & $\alpha$ & Rs & {$[\alpha]_{546}^{25}$} & ee \\
\hline Analytical separation & $\begin{array}{l}1^{\text {st }} \text { eluted enantiomer } \\
2^{\text {nd }} \text { eluted enantiomer }\end{array}$ & 5.47 & 0.85 & 7.73 & 1.62 & 1.90 & 4.02 & & \\
\hline Preparative separation & $\begin{array}{l}1^{\text {st }} \text { collected fractions } \\
2^{\text {nd }} \text { collected fractions }\end{array}$ & $\begin{array}{l}5.48 \\
5.65\end{array}$ & & $\begin{array}{l}8.10 \\
7.61\end{array}$ & & & & $\begin{array}{l}+650( \pm 50)^{c} \\
-650( \pm 50)^{d}\end{array}$ & $\begin{array}{l}>99 \% \\
>96 \%\end{array}$ \\
\hline${ }^{a}$ Detected CD sign at 2 & $\mathrm{~nm} .{ }^{b}$ Recorded in me & nol. ${ }^{c}$ wit & $=0$ & g. $\mathrm{cm}^{-3} \cdot{ }^{d}$ & h c & 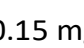 & $\mathrm{cm}^{-3}$. & & \\
\hline
\end{tabular}

\section{Chiral HPLC separation and chirality analysis.}

The DDQ insertion in the $\mathrm{C}-\mathrm{H}$ bond of $\mathbf{4 a - c}$ results in the formation of a quaternary stereogenic carbon atom in the corresponding adducts 11a-c. Consequently, an analytical chiral HPLC analysis of 11a was conducted in order to see if its two enantiomers could be separated and therefore characterized. After screening different chiral stationary phases and solvents, a so called $(S, S)$-WhelkO1 column was chosen with a mobile phase combining $n$-heptane, dichloromethane and ethanol containing $0.1 \%$ of trifluoroacetic acid (TFA) in an overall 10/10/80 ratio. The addition of an organic acid was required to ensure the elution of the highly polar 11a. These experimental conditions afforded a good enantioselectivity factor $\alpha(1.90)$ and a high resolution Rs (4.02) for the enantiomeric separation of 11a (Table 1 and Figure 5). Nevertheless, we observed the enantiomerization of each separated enantiomer in the acidic mobile phase during the storage of their collected fractions. A subsequent analysis in the acidic mobile phase gave a corresponding enantiomerization barrier of $96.2 \mathrm{~kJ} \cdot \mathrm{mol}^{-1}$ and a half-time value of 65 minutes at $25^{\circ} \mathrm{C}$ (see the experimental part and the supporting information).

If this racemization process is quite fast in acidic medium, it is completely stopped when a concentrated ethanol solution of sodium carbonate is added during the collection of the separated fractions. 


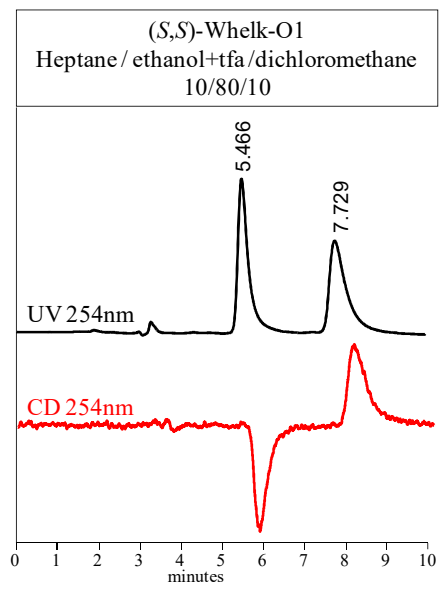

Fig 5. Chromatograms of the chiral HPLC analysis of the racemic 11a: UV and Circular Dichroism detection at $254 \mathrm{~nm}$ on (S,S)-Whelk-O1 using heptane / ethanol and tfa / dichloromethane $(1 / 8 / 1)$ as a mobile phase and at $1 \mathrm{~mL} \cdot \mathrm{min}^{-1}$.

Therefore, using this strategy and the same experimental conditions (stationary and mobile phases), a chiral separation was conducted on a preparative scale giving up to $25 \mathrm{mg}$ of each enantiomer of 11a with an optical purity exceeding $96 \%$ (Table 1 ). The two enantiomers of 11a give an identical UV-visible spectrum (recorded in the neutralized mobile phase) featuring three intense absorption bands located at ca. 220, 340 and $350 \mathrm{~nm}$ that were previously attributed to $\pi \rightarrow \pi^{*}$ transitions of the zwitterionic part (Figure 6). ${ }^{17}$ On the other hand, the fourth band at ca. $270 \mathrm{~nm}$ could be due to the reduced DDQ moiety. ${ }^{18}$ The ECD spectrum of the second eluted enantiomer features multiple Cotton effects and is, as expected, the mirror-image of the ECD spectrum recorded for the first eluted one (Figure 6). The same symmetry is observed when measuring the values of the optical rotations in methanol at $546 \mathrm{~nm}$ which reaches up to $+650^{\circ}$ for the first eluted enantiomer (Table 1 ).
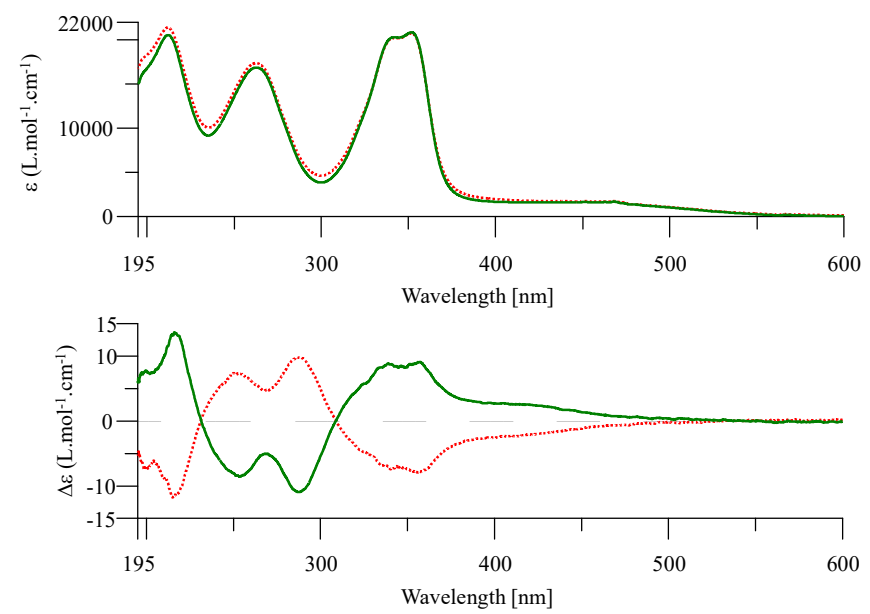

Fig 6. UV-visible (top) and ECD spectra (below) of the first (green solid line) and the second (red dotted line) eluted enantiomers of 11a (recorded in methanol).

\section{Racemization mechanism}

If the addition of DDQ on 4a-c is extending the number of such zwitterionic C-substituted derivatives, it is particularly appealing for its concomitant and unprecedented introduction of a chiral centre appended on the upper O-C-C-C-O moiety. This functionalization would be complementary to the single previously reported chiral derivatization of 4 that was performed thanks to the introduction of chiral amines on its lower $\mathrm{N}-\mathrm{C}-\mathrm{C}-\mathrm{C}-\mathrm{N}$ part. ${ }^{4 \mathrm{e}}$ Considering that the use of 11a-c as chiral ligands requires experimental conditions that prevent its racemization, two preliminary experiments were conducted to give first insights of the corresponding racemization process.

The first one was the determination of the racemization barrier that showed a first-order kinetic when using an acidic solution (see the supporting information). If the Michael addition is often used to create chiral centres, it can compete with its reversible dissociation in a Michael-retro-Michael tandem process. ${ }^{19}$ This process was found to be responsible of the racemization of 11a because the ${ }^{1} \mathrm{H}$ NMR spectrum of an equimolar mixture of 11a and $4 \mathrm{c}$ (in DMSO- $\mathrm{d}_{6}$ ) produces in less than 20 minutes the appearance of traces of the cross coupling products $4 \mathrm{a}$ and 11c (Figure 7 and Figure S2 in the SI). Within 18 hours, 
this exchange produces an almost equimolar mixture of the four components $\mathbf{4 a}, \mathbf{4 c}, \mathbf{1 1} \mathbf{a}$ and 11c which are distinguished from one to another in the corresponding ${ }^{1} \mathrm{H}$ NMR spectrum by the different chemical shifts of their quinoidal $\mathrm{H}_{\mathrm{a}}$ and $\mathrm{H}_{\mathrm{b}}$ signals (Figure 7 and Figure S2 in the SI). Because no external acidic source was added during this experiment, the retro-Michael process is probably induced or catalyzed by the partially dissociated phenolic and acidic protons $\mathrm{H}_{\mathrm{c}}$ (Figure 7 ) which are inactive when a base is added. Moreover the absence of any detectable traces of 4a-c in the ${ }^{1} \mathrm{H}$ NMR of 11a-c shows that if the Michael -retroMichael equilibrium is responsible of the racemization of 11a, it must be largely shifted toward the formation of the 4-DDQ adducts.

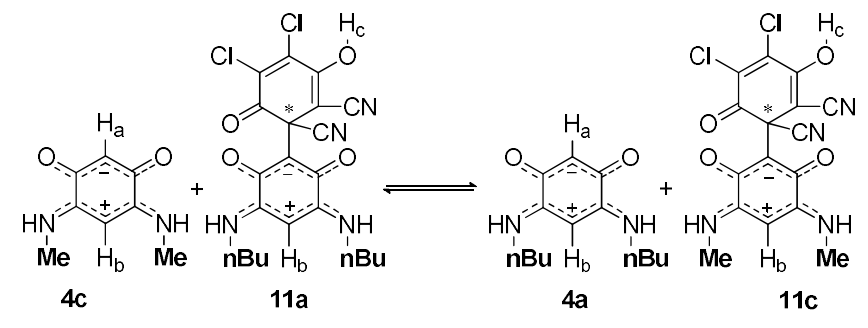

Fig 7. Michael-retro-Michael exchange between $\mathbf{4 c}$ and 11 a producing $4 \mathrm{a}$ and $\mathbf{1 1 c}$.

\section{Experimental}

\section{Materials and methods.}

Compounds 4 a-c were prepared according to literature procedure. ${ }^{3 b}$ All the reagents and anhydrous solvents were purchased from Alfa Aesar or Sigma Aldrich and were used without further purification. Column chromatography was performed using silica gel (60-120 mesh). Analytical thin layer chromatography (TLC) was performed on precoated silica gel-60 F254 (0.5 mm) aluminium plate. Visualization of the spots on TLC plates was achieved by exposure to UV light. ${ }^{1} \mathrm{H}$ and ${ }^{13} \mathrm{C}$ NMR spectra were recorded on a JEOL ECS400 NMR spectrometer. Chemical shifts are reported in delta $(\delta)$ units, expressed in parts per million using the residual protonated solvent signal as an internal standard (For proton: $\mathrm{CDCl}_{3}, 7.26 \mathrm{ppm}$; Acetone- $\mathrm{d}_{6}, 2.05$ ppm. For ${ }^{13} \mathrm{C}$ : $\mathrm{CDCl}_{3}, 77.0 \mathrm{ppm}$; Acetone- $\mathrm{d}_{6}, 30.8 \mathrm{ppm}$. The multiplicity of the signals is designated by the following abbreviations: $\mathrm{s}$, singulet; br $\mathrm{s}$, broad singulet; $d$, doublet; $t$, triplet; br $t$, broad triplet; $m$, multiplet. Coupling constants, $J$, are reported in Hertz (Hz). Highresolution mass spectrometry (HRMS) analysis was performed on a SYNAPT G2 HDMS (Waters). Absorption spectra were recorded using $1 \mathrm{~mm}$ and $10 \mathrm{~mm}$ quartz cells in a Varian Cary 50 UV-vis spectrophotometer and spectroscopic grade solvents. ECD and UV spectra recorded subsequently to the chiral separation were measured on a JASCO J-815 spectrometer equipped with a JASCO Peltier cell holder PTC-423 to maintain the temperature at $25.0 \pm 0.2^{\circ} \mathrm{C}$. A $1 \mathrm{~mm} \mathrm{CD} \mathrm{quartz}$ cell was used. The CD spectrometer was purged with nitrogen before recording each spectrum, which was baseline subtracted. The baseline was always measured for the same solvent and in the same cell as the samples. The ECD spectra are presented without smoothing and further data processing. Optical rotations were measured on a 241 Perkin-Elmer polarimeter with a mercury lamp at $546 \mathrm{~nm}$ and a double-jacketed $10 \mathrm{~cm}$ cell at $25^{\circ} \mathrm{C}$.

\section{Organic Synthesis}

11a: To a solution of 4 a (300 mg, $1.21 \mathrm{mmol}, 1$ equiv.) in $\mathrm{CH}_{2} \mathrm{Cl}_{2}$ (40 mL), was added DDQ (300 mg, $1.32 \mathrm{mmol}, 1.1 \mathrm{equiv}$ ). The mixture was stirred at room temperature overnight before toluene $(20 \mathrm{~mL})$ was added. Most of the $\mathrm{CH}_{2} \mathrm{Cl}_{2}$ was evaporated under reduced pressure. The resulting precipitate was collected by filtration and successively washed with toluene and $\mathrm{Et}_{2} \mathrm{O}$. $\mathrm{A} \mathrm{drying}_{\mathrm{in}}$ under vacuum afforded the desired product $11 \mathrm{a}$ as a red powder $(536 \mathrm{mg}, 1.12 \mathrm{mmol}, 93 \%) .{ }^{1} \mathrm{H} \mathrm{NMR}\left(400 \mathrm{MHz}, \mathrm{DMSO}-\mathrm{d}_{6}, 294\right.$ $\mathrm{K}): \delta=9.37\left(\mathrm{br} \mathrm{t},{ }^{3} \mathrm{~J}_{H H}=6.3 \mathrm{~Hz}, 2 \mathrm{H}\right), 5.59(\mathrm{~s}, 1 \mathrm{H}), 3.42(\mathrm{~m}, 4 \mathrm{H}), 1.58$ (quint, $\left.{ }^{3} \mathrm{~J}_{H H}=7.3 \mathrm{~Hz}, 4 \mathrm{H}\right), 1.31\left(\mathrm{sext},{ }^{3} \mathrm{~J}_{H H}=7.3 \mathrm{~Hz}, 4 \mathrm{H}\right), 0.90$ $\operatorname{ppm}\left(\mathrm{t},{ }^{3} J_{H H}=7.3 \mathrm{~Hz}, 6 \mathrm{H}\right) ;{ }^{1} \mathrm{H}$ NMR $\left(400 \mathrm{MHz}, \mathrm{MeOD}-\mathrm{d}_{4}, 294 \mathrm{~K}\right): \delta=5.58(\mathrm{~s}, 1 \mathrm{H}), 3.48\left(\mathrm{t},{ }^{3} J_{H H}=7.2 \mathrm{~Hz}, 4 \mathrm{H}\right), 1.69\left(\mathrm{quint},{ }^{3} J_{H H}=7.3\right.$ $\mathrm{Hz}, 4 \mathrm{H}$ ), 1.44 (sext, $\left.{ }^{3} \mathrm{~J}_{H H}=7.3 \mathrm{~Hz}, 4 \mathrm{H}\right), 0.99 \mathrm{ppm}\left(\mathrm{t},{ }^{3} \mathrm{~J}_{H H}=7.3 \mathrm{~Hz}, 6 \mathrm{H}\right) ;{ }^{13} \mathrm{C} \mathrm{NMR}\left(100 \mathrm{MHz}, \mathrm{DMSO}-\mathrm{d}_{6}, 294 \mathrm{~K}\right): \delta=180.3,169.0,154.4$, $154.3,143.1,135.0,115.5,115.1,106.3,87.7,81.7,47.0,42.6,29.8,19.5,13.6 \mathrm{ppm}$; UV-Vis (DMSO): $\lambda_{\max }\left(\varepsilon \times 10^{-3}\right)=348(25.1)$, 359 (25.7), $489 \mathrm{~nm}$ (1.6); HRMS (ESI-TOF): calcd for $\mathrm{C}_{22} \mathrm{H}_{23} \mathrm{~N}_{4} \mathrm{O}_{4} \mathrm{Cl}_{2}{ }^{+}\left([\mathrm{M}+\mathrm{H}]^{+}\right)$477.1091, found 477.1090.

11b: To a solution of $\mathbf{4 b}$ (100 mg, $0.602 \mathrm{mmol}, 1$ equiv.) in $\mathrm{MeOH}(6 \mathrm{~mL})$, was added $\mathrm{DDQ}$ ( $\mathrm{m}=150 \mathrm{mg}, 0.661 \mathrm{mmol}, 1.1$ equiv.). The mixture was stirred at room temperature overnight. The resulting precipitate was filtered off, washed with $\mathrm{MeOH}$ and $\mathrm{CH}_{2} \mathrm{Cl}_{2}$. A crystallization from hot toluene afforded the desired product $11 \mathrm{~b}$ as a red powder $(177 \mathrm{mg}, 0.450 \mathrm{mmol}, 75 \%) .{ }^{1} \mathrm{H} \mathrm{NMR}$ $\left(400 \mathrm{MHz}, \mathrm{DMSO}-\mathrm{d}_{6}, 294 \mathrm{~K}\right): \delta=9.47(\mathrm{~m}, 2 \mathrm{H}), 5.46(\mathrm{~s}, 1 \mathrm{H}), 3.01 \mathrm{ppm}\left(\mathrm{d},{ }^{3} \mathrm{~J}_{\mathrm{HH}}=5.2 \mathrm{~Hz}, 6 \mathrm{H}\right) ;{ }^{13} \mathrm{C} \mathrm{NMR}\left(100 \mathrm{MHz}, \mathrm{DMSO}-\mathrm{d}_{6}, 294 \mathrm{~K}\right): \delta$ 
$=180.3,169.1,155.2,154.3,142.9,135.0,115.5,115.1,106.3,87.7,81.9,46.9,30.0 \mathrm{ppm} ;$ UV-Vis $(\mathrm{DMSO}): \lambda_{\max }\left(\varepsilon \times 10^{-3}\right)=344$ (25.0), 356 (25.9), $478 \mathrm{~nm}$ (1.4); HRMS (ESI-TOF): calcd. for $\mathrm{C}_{16} \mathrm{H}_{11} \mathrm{~N}_{4} \mathrm{O}_{4} \mathrm{Cl}_{2}^{+}\left([\mathrm{M}+\mathrm{H}]^{+}\right)$393.0152, found 393.0151.

7c: To a solution of $4 \mathrm{c}(40 \mathrm{mg}, 0.177 \mathrm{mmol}, 1$ equiv.) in $\mathrm{MeOH}(4 \mathrm{~mL})$ was added DDQ (41 mg, $0.181 \mathrm{mmol}, 1.02 \mathrm{equiv}$.). The mixture was stirred at room temperature overnight. The resulting precipitate was filtered off, washed successively with $\mathrm{MeOH}$ and $\mathrm{CH}_{2} \mathrm{Cl}_{2}$ before it was dried under vacuum affording the desired product 11c as an orange powder (36 $\mathrm{mg}, 0.079 \mathrm{mmol}, 45 \%$ ); ${ }^{1} \mathrm{H}$ NMR $(400 \mathrm{MHz}$, DMSO-d $6,294 \mathrm{~K}): \delta=9.23$ (brs , 2H), $5.73(\mathrm{~s}, 1 \mathrm{H}), 3.62(\mathrm{~m}, 4 \mathrm{H}), 3.48 \mathrm{ppm}(\mathrm{m}, 4 \mathrm{H}) ;{ }^{13} \mathrm{C} \mathrm{NMR}(100 \mathrm{MHz}, \mathrm{DMSO}-$ $\left.\mathrm{d}_{6}, 294 \mathrm{~K}\right): \delta=180.4,168.9,155.0,154.6,143.4,134.9,115.6,115.4,106.3,87.1,82.5,58.7,47.0,45.7 \mathrm{ppm}$; UV-Vis (DMSO): $\lambda_{\max }$ $\left(\varepsilon \times 10^{-3}\right)=347(25.3), 358(25.5), 491 \mathrm{~nm}(1.7)$; HRMS (ESI-TOF): calcd for $\mathrm{C}_{18} \mathrm{H}_{15} \mathrm{~N}_{4} \mathrm{O}_{6} \mathrm{Cl}_{2}^{+}\left([\mathrm{M}+\mathrm{H}]^{+}\right) 453.0363$, found 453.0363 .

\section{Chiral HPLC}

The chiral HPLC analyses and separations were performed on Agilent 1260 Infinity unit (pump G1311C, autosampler G1329B, DAD G1365D). A Jasco CD-2095 circular dichroism detector is implemented for the chiroptical detection. The sign given by the on-line circular dichroïsm at $254 \mathrm{~nm}$ is the sign of the compound in the solvent used for the chromatographic separation. The preparative chiral HPLC separation was performed using an Agilent 1260 Infinity unit (pump G1311C, autosampler G1329B, DAD G1365D and fraction collector G1364C). The $(S, S)$-Whelk-O1 analytical $(250 \times 4.6 \mathrm{~mm})$ and preparative columns $(250 \times 10 \mathrm{~mm}, 5$ $\mu \mathrm{m})$ are purchased from Regis Technologies (Morton Grove, USA) and are mainly composed of $(3 R, 4 S)$-4-(3,5-dinitrobenzamido)3-[3-(dimethylsilyloxy)propyl]-1,2,3,4-tetrahydrophenanthrene molecules (selectors) bonded onto silica. HPLC grade Heptane, ethanol and dichloromethane, were degassed and filtered on a $0.45 \mu \mathrm{m}$ millipore membrane before use. Retention times Rt (in minutes), retention factors $k_{i}=\left(R t_{i}-R t_{0}\right) / R t_{0}$, enantioselectivity factors $\alpha=k_{2} / k_{1}$ and resolution $R s=1.18\left(R t_{2}-R t_{1}\right) /\left(w_{1}+w_{2}\right)$ are given. $\mathrm{Rt}_{0}$ is determined by the injection of tri-tertio-butyl benzene and $\mathrm{w}_{\mathrm{i}}$ is the peak width at half-height.

The analysis of the 11a enantiomer's racemization in the acidic mobile phase was performed starting from a solution of ca. $0.5 \mathrm{mg}$ of the second eluted enantiomer dissolved in $1 \mathrm{~mL}$ of the mobile phase and thermostated at $25^{\circ} \mathrm{C}$. Every 12 minutes, 10 $\mu \mathrm{L}$ of this solution was injected on the chiral phase giving a decreasing percentage of the second eluted enantiomer that was monitored.

\section{Single crystal X-ray diffraction}

The intensity data for compound 11a were collected on a Rigaku Oxford Diffraction SuperNova diffractometer using CuK $\alpha$ radiation $(\lambda=1.54184 \AA$ A). Data collection, cell refinement and data reduction were performed with CrysAlisPro (Rigaku Oxford Diffraction). The structure was solved with shelXT ${ }^{20}$ and shel $\mathrm{XL}^{20}$ was used for full matrix least squares refinement. The crystal appeared to be twinned and both domains were refined together using the HKLF5 shelXL instruction to final values of BASF equal to $0.553(2)$ and $0.447(2)$ respectively. One aminobutyl was found to be disordered and was refined on two sites of equal occupation 0.5 . The hydrogen atoms were all found experimentally except those of the disordered moiety that were introduced at geometrical positions. Their Uiso parameters were fixed to $1.2 \mathrm{Ueq}$ (parent atom) for the aromatics and $\mathrm{CH}_{2}$ carbons and the amine and to $1.5 \mathrm{Ueq}$ (parent atom) for the methyls and $\mathrm{OH}$ group. CCDC-1572929 (11a) contains the supplementary crystallographic data. These data can be obtained free of charge from The Cambridge Crystallographic Data Centre via www.ccdc.cam.ac.uk/data request:cif.

\section{Conclusions}

The addition of the electron accepting DDQ on the benzoquinonemonoimine 4a-c results in a C-C bond formation occurring regioselectively on the $\mathrm{O}-\mathrm{C}-\mathrm{C}-\mathrm{C}-\mathrm{O}$ part of the zwitterionic reactant. This Michael type addition produces the chiral adducts $\mathbf{1 1 a - c}$ which retain a zwitterionic form thanks to an intramolecular proton transfer. The optically pure enantiomers of these new quinoidal bridging ligands can be separated and characterized as long as a basic medium is used to prevent their acid-catalysed racemizations that are probably following a retro-Michael process. This unprecedented chiral functionalization of the zwitterionic 4 offers a new entry in chiral zwitterionic quinoidal bridging and coordinating ligands that could be used, for example, in the design of chiral polymetallic structures or redox-active complexes build previously on the parent compound 1 and its derivatives. ${ }^{21}$

\section{Acknowledgements}

This work was supported by the Centre National de la Recherche Scientifique, the Ministère de la Recherche et des Nouvelles Technologies (PhD grant to Z. C.). 


\section{Notes and references}

1 a) P. Chaudhuri and K. Oder, J. Chem. Soc., Dalton Trans., 1990, 1597; b) S. Kitagawa and S. Kawata, Coord. Chem. Rev., 2002, 224, 11; c) C. Carbonera, A. Dei, J.-F. Létard, C. Sangregorio and L. Sorace, Angew. Chem. Int. Ed., 2004, 43, 3136; d) J. Tao, H. Maruyama and O. Sato, J. Am. Chem. Soc., 2006, 128, 1790.

2 a) P. Saha, A. Saha Roy, T. Weyhermuller and P. Ghosh, Chem. Commun., 2014, 50, 13073; b) B. Sarkar, D. Schweinfurth, N. Deibel and F. Weisser, Coord. Chem. Rev., 2015, 293, 250; c) M. van der Meer, Y. Rechkemmer, U. Frank, F. D. Breitgoff, S. Hohloch, C.-Y. Su, P. Neugebauer, R. Marx, M. Dörfel, J. van Slageren and B. Sarkar, Chem. Eur. J., 2016, 22, 13884; d) M. van der Meer, Y. Rechkemmer, F. D. Breitgoff, S. Dechert, R. Marx, M. Dörfel, P. Neugebauer, J. van Slageren and B. Sarkar, Dalton Trans., 2016, 45, 8394; e) M. van der Meer, Y. Rechkemmer, F. D. Breitgoff, R. Marx, P. Neugebauer, U. Frank, J. van Slageren and B. Sarkar, Inorg. Chem., 2016, 55, 11944. f) S. Pascal and O. Siri, Coord. Chem. Rev., 2017, 350, 178.

3 a) O. Siri and P. Braunstein, Chem. Commun., 2002, 208; b) Q.-Z. Yang, O. Siri and P. Braunstein, Chem. Commun., 2005, 2660; c) Q.-Z. Yang, O. Siri and P. Braunstein, Chem. Eur. J., 2005, 11, 7237.

4 a) D. A. Kunkel, S. Simpson, J. Nitz, G. A. Rojas, E. Zurek, L. Routaboul, B. Doudin, P. Braunstein, P. A. Dowben and A. Enders, Chem. Commun., 2012, 48, 7143; b) S. Simpson, D. A. Kunkel, J. Hooper, J. Nitz, P. A. Dowben, L. Routaboul, P. Braunstein, B. Doudin, A. Enders and E. Zurek, J. Phys. Chem. C, 2013, 117, 16406; c) M. Koudia, E. Nardi, O. Siri and M. Abel, Nano Res., 2017, 10, 933

5 a) J.-P. Taquet, O. Siri, P. Braunstein and R. Welter, Inorg. Chem., 2004, 43, 6944; b) H. S. Das, A. K. Das, R. Pattacini, R. Hübner, B. Sarkar and P. Braunstein, Chem. Commun., 2009, , 4387; c) P. Braunstein, D. Bubrin and B. Sarkar, Inorg. Chem., 2009, 48, 2534; d) A. Paretzki, R. Pattacini, R. Huebner, P. Braunstein and B. Sarkar, Chem. Commun., 2010, 46, 1497; e) N. Deibel, D. Schweinfurth, R. Huebner, P. Braunstein and B. Sarkar, Dalton Trans., 2011, 40, 431; f) A. Ghisolfi, A. Waldvogel, L. Routaboul and P. Braunstein, Inorg. Chem., 2014, 53, 5515; g) M. Yuan, F. Weisser, B. Sarkar, A. Garci, P. Braunstein, L. Routaboul and B. Therrien, Organometallics, 2014, 33, 5043; h) P. Kar, M. Yoshida, A. Kobayashi, L. Routaboul, P. Braunstein and M. Kato, Dalton Trans., 2016, 45, 14080.

6 a) Q.-Z. Yang, A. Kermagoret, M. Agostinho, O. Siri and P. Braunstein, Organometallics, 2006, 25, 5518; b) S. Hohloch, P. Braunstein and B. Sarkar, Eur. J. Inorg. Chem., 2012, 2012, 546.

7 P. Braunstein, O. Siri, P. Steffanut, M. Winter and Q.-Z. Yang, C. R. Chim., 2006, 9, 1493.

8 N. Deibel, S. Hohloch, M. G. Sommer, D. Schweinfurth, F. Ehret, P. Braunstein and B. Sarkar, Organometallics, $2013,32,7366$.

9 P. Kar, M. Yoshida, Y. Shigeta, A. Usui, A. Kobayashi, T. Minamidate, N. Matsunaga and M. Kato, Angew. Chem. Int. Ed., 2017, 56, 2345.

10 P. Braunstein, O. Siri, J.-P. Taquet, M.-M. Rohmer, M. Bénard and R. Welter, J. Am. Chem. Soc., 2003, 125, 12246.

11 P. Braunstein, O. Siri, J.-P. Taquet and Q.-Z. Yang, Angew. Chem. Int. Ed., 2006, 45, 1393.

12 A) T. Kauf and P. Braunstein, Dalton Trans., 2011, 40, 9967; b) T. Kauf and P. Braunstein, Inorg. Chem., 2011, 50, 11472; c) L. Kong, L. Routaboul, P. Braunstein, H.-G. Park, J. Choi, J. P. C. Cordova, E. Vega, L. G. Rosa, B. Doudin and P. A. Dowben, RSC Adv., 2013, 3, 10956; d) T. Kauf, V. Rosa, C. Fliedel, R. Pattacini, N. Deibel, T. Avilés, B. Sarkar and P. Braunstein, Dalton Trans., 2015, 44, 5441; e) M. Yuan, I. Tanabe, J.-M. Bernard-Schaaf, Q.-Y. Shi, V. Schlegel, R. Schurhammer, P. A. Dowben, B. Doudin, L. Routaboul and P. Braunstein, New J. Chem., 2016, 40, 5782.

13 J.-P. Taquet, O. Siri, J.-P. Collin, A. Messaoudi and P. Braunstein, New J. Chem., 2005, 29, 188.

14 a) A. Bhattacharya, L. M. DiMichele, U. H. Dolling, E. J. J. Grabowski and V. J. Grenda, J. Org. Chem., 1989, 54, 6118; b) V. G. Saraswathy and S. Sankararaman, J. Org. Chem., 1995, 60, 5024; c) X. Guo and H. Mayr, J. Am. Chem. Soc., 2013, $135,12377$.

15 U. Kucklaender, R. Bollig, W. Frank, A. Gratz and J. Jose, Bioorg. Med. Chem., 2011, 19, 2666.

16 R. Manivannan and K. P. Elango, New J. Chem., 2016, 40, 1554.

17 D. Delaere, P.-C. Nam and M. Tho Nguyen, Chem. Phys. Lett., 2003, 382, 349.

18 The origin of this band is beyond the scope of the present study.

19 a) J. R. Harrison, P. O'Brien, D. W. Porter and N. M. Smith, J. Chem. Soc., Perkin Trans. 1, 1999, 3623 ; b) K. Tan, R. Alvarez, M. Nour, C. Cavé, A. Chiaroni, C. Riche and J. d'Angelo, Tetrahedron Lett., 2001, 42, 5021 ; c) J. A. Pesti, J. Yin, L.-h. Zhang and L. Anzalone, J. Am. Chem. Soc., 2001, 123, 11075; d) M. Pizzonero, F. Hendra, S. Delarue-Cochin, M.-E. Tran Huu-Dau, F. Dumas, C. Cavé, M. Nour and J. d'Angelo, Tetrahedron: Asymmetry, 2005, 16, 3853; e) C. Uncuta, G. B. Caraman, C. I. Tanase, E. Bartha, V. C. Kravtsov, Y. A. Simonov, J. Lipkowski, N. Vanthuyne and C. Roussel, Chirality, 2005, 17, 63; f) Y.-F. Cai, L. Li, M.-X. Luo, K.-F. Yang, G.-Q. Lai, J.-X. Jiang and L.-W. Xu, Chirality, 2011, 23, 397.

20 G. M. Sheldrick, Acta Cryst., 2015, C71, 3.

21 a) B. Therrien and G. Suss-Fink, Chimia, 2008, 62, 514; b) T. Moriuchi and T. Hirao, Acc. Chem. Res., 2012, 45, 347; c) Y. Kubota, T. Niwa, J. Jin, K. Funabiki and M. Matsui, Org. Lett., 2015, 17, 3174. 